\title{
Biological potency of porcine, bovine and human insulins in the rabbit bioassay system
}

\author{
M. Pingel ${ }^{1}$, Aa. Vølund ${ }^{1}$, E. Sørensen ${ }^{1}$, J. E. Collins ${ }^{2}$ and C.T. Dieter ${ }^{2}$ \\ ${ }^{1}$ Novo Research Institute, Novo Allé, DK-2880 Bagsvaerd, Denmark and \\ ${ }^{2}$ Food and Drug Administration, HFN 172, 200 C Street, SW Washington, DC 20204, USA
}

\begin{abstract}
Summary. Potency determination of porcine, bovine and human insulins relative to the International Standard in the pharmacopoeial rabbit bioassay system requires that the logdose response curves are parallel. Furthermore, the same relative potency should be obtained independent of how the hypoglycaemic response is defined. The results of 508 rabbit blood glucose assays have been analyzed by new multivariate statistical methods. No deviations from parallelism of the logdose response curves were detected. However, the potencies showed significant variation depending on the blood sampling times. Pure porcine and human (semisynthetic and biosynthetic) insulin potencies decreased by $12 \%$ and $18 \%$, respectively, from the $30-\mathrm{min}$ to the 2.5 -h response, whereas bovine insulin potencies increased by $9 \%$. Since the standard is a
\end{abstract}

52:48 mixture of bovine and porcine insulins, these results could be due to porcine and human insulins having a quicker onset and shorter duration of hypoglycaemic effect than bovine insulin. This was confirmed in assays of bovine relative to porcine insulin and by direct comparison of mean blood glucose curves. It is concluded that there is a response time-dependent variation in potency when the test and standard insulin have a different species composition. Hence, pure species insulin standards - a porcine, a bovine and a human standard - are needed for assay of the three insulins.

Key words: Bovine insulin, porcine insulin, human insulin, biological potency, rabbit bioassay, duration of hypoglycaemic effect, multivariate statistical analysis.
Differences in amino acid sequence between porcine, bovine and human insulin give rise to different physicochemical properties [1-3] which are used in preparing pharmaceutical insulin preparations with different timing of action [4]. The different physico-chemical properties could cause a different hypoglycaemic effect in the pharmacopoeial bioassays which would render the results invalid if the test and standard insulin were of different species composition. A prerequisite for using the rabbit blood glucose assay for potency determination of bovine, porcine and human insulins relative to the present mixed bovine/porcine insulin standard is that the three insulin species exert similar hypoglycaemic effects in rabbits, i. e. the log-dose response curves must be parallel, and the same relative potency should be obtained independent of the response definition. However, an analysis of rabbit blood glucose assays by new multivariate statistical methods has shown that the relative potencies of porcine and bovine insulins based on blood glucose responses $30 \mathrm{~min}, 1 \mathrm{~h}$ and $2.5 \mathrm{~h}$ after the injection are significantly different [5].

In the present investigation results of 508 rabbit blood glucose assays of porcine, bovine and human in- sulins carried out in two different laboratories and in two different strains of rabbits are analysed by the multivariate statistical methods $[6,7]$ in order to determine how the potency of these insulins relative to the International mixed species Standard or to a pure pork insulin standard depends on the blood sampling time. The results of some of the previously analysed assays [5] are included in the extended and more detailed analyses given here.

\section{Materials and methods}

\section{Insulins}

A total of 74 insulin batches were examined, 72 of which were manufactured between 1972 and 1983 by Novo Industrie, Copenhagen, Denmark and used for pharmaceutical insulin preparations for the treatment of diabetes mellitus. The remaining two insulins were two batches of Humulin (Neutral Regular Human Insulin) made from biosynthethic human insulin produced by Eli Lilly \& $\mathrm{Co}$, Indianapolis, Indiana, USA. Fifteen batches recrystallized (RC) porcine insulin, 24 batches $\mathrm{RC}$ bovine insulin, 19 batches monocomponent (MC) porcine insulin, nine batches MC bovine insulin, five batches MC human insulin (semisynthetic) and two batches biosynthetic (BS) human insulin were studied. 
Table 1. Content of various contaminants (pancreatic proteins and polypeptides) in the insulins as determined by radioimmunoassays: proinsulin-like substances [13], glucagon-like substances [14], pancreatic polypeptide [15], somatostatin [16] and vasoactive intestinal polypeptide [17]

\begin{tabular}{|c|c|c|c|c|}
\hline \multirow[t]{2}{*}{ Contaminants } & \multirow{2}{*}{$\begin{array}{l}\text { MC insulins } \\
\text { (porcine, } \\
\text { bovine and } \\
\text { human) }\end{array}$} & \multicolumn{2}{|c|}{$\begin{array}{l}\text { Recrystallized } \\
\text { insulins }\end{array}$} & \multirow{2}{*}{$\begin{array}{l}\text { Fourth } \\
\text { Inter- } \\
\text { national } \\
\text { Standard }\end{array}$} \\
\hline & & Porcine & Bovine & \\
\hline $\begin{array}{l}\text { Proinsulin-like } \\
\text { substances }\end{array}$ & $\leqslant 1$ & $\sim 15000$ & $\sim 25000$ & 30000 \\
\hline $\begin{array}{c}\text { Glucagon-like } \\
\text { substances }\end{array}$ & $\leqslant 0.1$ & $\sim 4$ & $\sim 10$ & 700 \\
\hline $\begin{array}{l}\text { Pancreatic poly- } \\
\text { peptide }\end{array}$ & $\leqslant 0.01$ & $\sim 3$ & $\sim 3$ & 17 \\
\hline Somatostatin & $\leqslant 0.01$ & $\sim 0.05$ & $\sim 0.07$ & 0.1 \\
\hline $\begin{array}{l}\text { Vasoactive intesti- } \\
\text { nal polypeptide }\end{array}$ & $\leqslant 0.01$ & $\sim 0.02$ & $\sim 0.03$ & 0.5 \\
\hline
\end{tabular}

All values are given in parts per million (ppm) by weight of the dry insulin

The porcine and bovine insulins were extracted from pork and beef pancreas glands, whereas the human insulins were made from either porcine insulin by enzymatic transpeptidation (semisynthetic human insulin) as described by Markussen [8] or by recombinant DNA technology (biosynthetic human insulin) as described by Chance et al. [9]. The RC insulins containing about $90 \%$ pure insulin were manufactured by conventional manufacturing processes without chromatographic purifications ending with four, and occasionally more, crystallizations of the insulin. The MC insulins were purified to more than $99 \%$ purity using a sequence of chromatographic purification processes including anion-exchange chromatography in an ethanolic medium [10-12].

Table 1 illustrates the purity of the RC and MC insulins by the content of pancreatic protein and polypeptide contaminants as determined by radioimmunoassays. For comparison, the content of these impurities in the Fourth International Standard for Insulin is shown as well. The human insulins, both those prepared by semisynthesis and purified to MC purity and those prepared by biosynthesis, are characterized by consisting of insulin, which in several chemical and physico-chemical tests behave identically with natural human insulin from human pancreas $[9,18]$. The most convincing single identity test for the semisynthetic as well as the biosynthetic human insulin is the comparison of X-ray diffraction patterns of the insulin crystals, which proves identity of sequence, conformation and state of aggregation with that of natural human insulin [1]. The purity and identity of the insulins as determined by various analytical methods including HPLC is described in more detail [12, 18, 19] ( $R C$ \& MC insulins); [9] (BS insulins).

\section{Bioassays}

The biological potency of the insulins was determined by the twin cross-over rabbit blood glucose assay procedure as described in the United States Pharmacopeia (USP) [20]. The majority of the bioassays were routine assays carried out in the Novo laboratory and the Food and Drug Administration laboratory (FDA) in connection with certification of batches of porcine, bovine and human insulins. The standard preparation was either the Fourth International Standard of Insulin - $52 \%$ bovine and $48 \%$ porcine insulin with a defined potency of 24.0 IU/mg [21] - or the USP Insulin Reference Standard G, which is identical to the International Standard. In addition, a number of bioassays of $\mathrm{MC}$ porcine, bovine and human insulin relative to $\mathrm{MC}$ porcine insulin were carried out.
For each assay, 28 (24) male or female rabbits of Rex White strain (Novo) weighing between 1.8 and $3.2 \mathrm{~kg}$ or New Zealand White strain (FDA \& Novo) weighing between 2.6 and $5.0 \mathrm{~kg}$ were used in a randomized twin cross-over design. The rabbits were used for about 5 assays per year within a living period of $1-3$ years (mean 2 years) in the laboratory. To secure that no insulin antibody formation, which could interfere with the bioassays, occurs in rabbits used this way, serum samples from a representative sample of 251 rabbits (approximately $20 \%$ of the rabbits used in this investigation) have been analyzed for insulin antibodies by adding ${ }^{125} \mathrm{I}$-ox-insulin and determining the percent bound to antibody as described by Schlichtkrull et al. [12]. Only 13 of the serum samples showed more than $8 \%$ bound insulin, which is the detection limit of the analysis, and the highest measured value was $13 \%$. The distribution of $\%$ bound was not different from that obtained on serum samples from rabbits never injected with insulin.

The rabbits were fasted $16-18 \mathrm{~h}$ before subcutaneous injection with dilutions of either the standard or the test preparation. Two dilutions of the standard and two dilutions of the test preparation containing 1.0 and $2.0 \mathrm{IU} / \mathrm{ml}$, respectively, were prepared by diluting portions of stock solutions $(40 \mathrm{IU} / \mathrm{ml})$ with a $1.6 \%$ glycerol solution acidified with hydrochlorid acid to $\mathrm{pH} 3$ and containing $0.1 \%$ phenol. The dilutions were stored at $4{ }^{\circ} \mathrm{C}$ and used within one week. The doses injected were either 0.40 and $0.80 \mathrm{IU} / \mathrm{rabbit}$ or 0.50 and $1.00 \mathrm{IU} / \mathrm{rabbit}$ with a period of 1 week (Novo) or one day (FDA) between the two injections. In some of the assays a blood sample was taken at $30 \mathrm{~min}$ after the injection in addition to the standardized $1 \mathrm{~h}$ and $2.5 \mathrm{~h}$ samples. In one set of assays samples were taken at $0.30 \mathrm{~min}, 1 \mathrm{~h}, 2.5 \mathrm{~h}$ and $4 \mathrm{~h}$ after the injection. All blood samples were $100 \mu \mathrm{l}$ (Novo) or $800 \mu \mathrm{l}$ (FDA) taken from the marginal ear vein. The blood glucose concentration was determined by autoanalyzer using either the ferricyanide method [22] or the hexokinase/glucose-6-phosphate dehydrogenase method [23]. The twin cross-over assay on 28 (24) rabbits was usually repeated four to six times and occasionally more, to obtain a potency estimate corresponding to a statistical weight of about 4000 or more. The statistical weight is defined as the reciprocal value of the variance of the $\log _{10}$ potency estimate, and the value of 4000 corresponds to a coefficient of variation of about $4 \%$. A total of 508 single assays was carried out, corresponding to the use of about 14,000 rabbits.

\section{Statistical analysis}

The results of the assays were analysed according to standard statistical methods for twin cross-over assays [24] using as response the sum of the $1 \mathrm{~h}$ and $2.5 \mathrm{~h}$ blood glucose values as described in the pharmacopeia (USP) [20]. In addition, recently developed multivariate methods $[6,7]$ were used to analyse the responses at the various sampling times to investigate time dependent differences in potency between the insulin species. The results from each assay were analysed by univariate and multivariate analysis of variance to check the parallelism of the dose response curves for the test and standard. The potency estimates based on the sum of the $1 \mathrm{~h}$ and $2.5 \mathrm{~h}$ responses of the repeated assays of the same insulin batch were combined according to the weighted mean method [20] which includes a $\chi^{2}$-test of homogeneity of the potencies. The multivariate potencies were combined according to maximum likelihood methods [7], which enable the testing of the homogeneity between responses (sampling times) and assays according to the two-way structure. First it was tested whether potency differences between responses and assays were additive (in log-potency); if they were, the differences between responses and assays could be tested, and combined potency estimates for each response could be calculated. Combined estimates for each response and batch were further combined to weighted mean potencies for batches of the same species and purity. Although there was statistically significant non-additivity in potency between assays and responses with a few batches, none were excluded, and the homogeneity of the potencies across batches was checked by means of $\chi^{2}$-tests. All the statistical analyses were carried out by means of specially developed APL computer programs. 
Table 2. Recrystallized porcine (RCP) and bovine (RCB) insulin batches relative to the International Standard

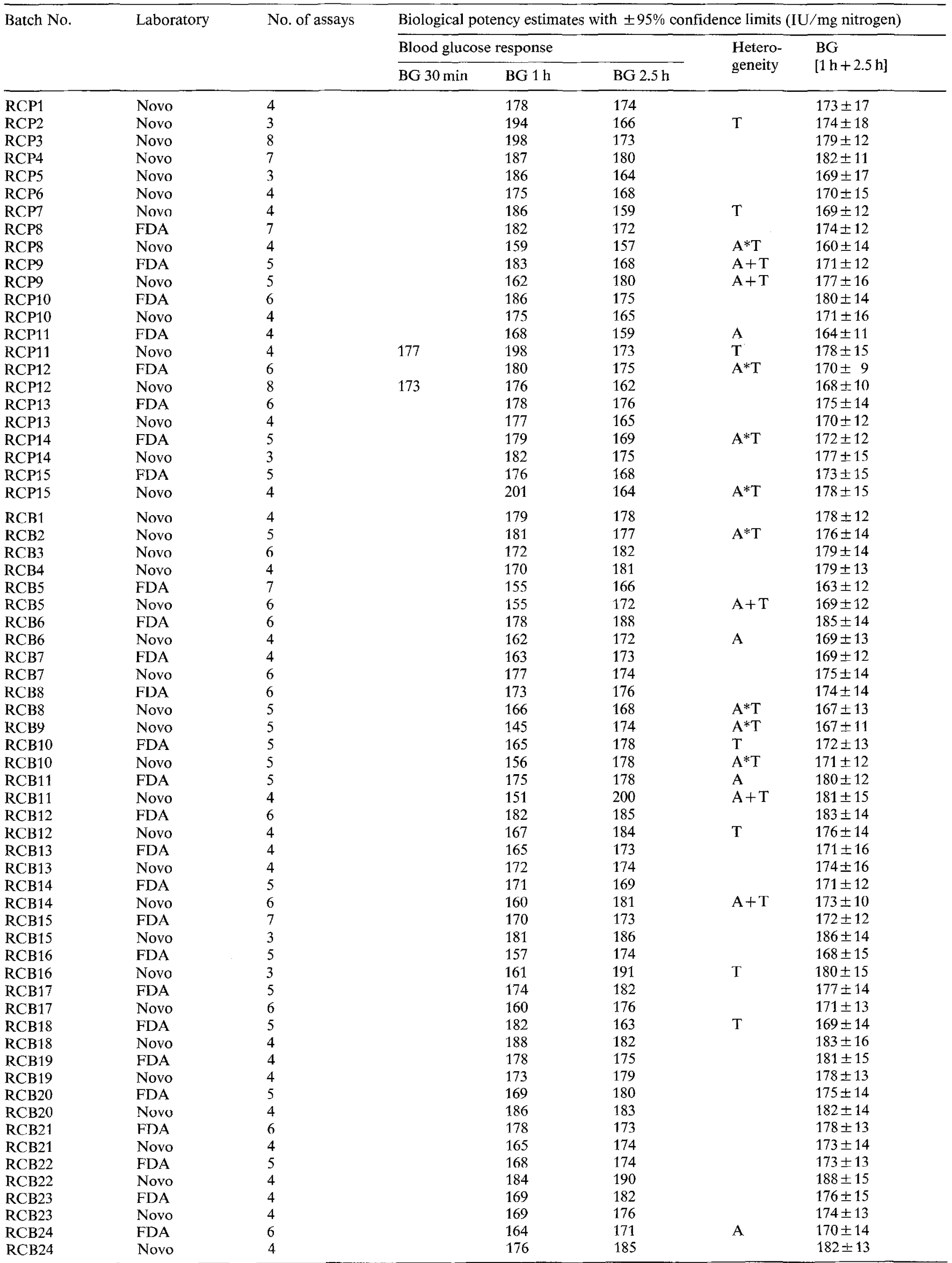

Statistically significant heterogeneity in potency $(p<0.05)$ is indicated as follows: $\mathrm{A}+\mathrm{T}$ : assays and sampling times (additive effects on log-potency), A*T: assays and sampling times (non-additive effects on log-potency), A: assays only, T: sampling times only 
Table 3. MC porcine, MC bovine, and MC and BS human insulin batches relative to the International Standard

\begin{tabular}{|c|c|c|c|c|c|c|c|}
\hline \multirow[t]{2}{*}{ Batch no. } & \multirow[t]{2}{*}{ Laboratory } & \multirow[t]{2}{*}{ No. of assays } & \multicolumn{5}{|c|}{ Biological potency estimates with $\pm 95 \%$ confidence limits (IU $/ \mathrm{mg}$ nitrogen or $\%$ ) } \\
\hline & & & $\mathrm{BG} 30 \mathrm{~min}$ & $\mathrm{BG} 1 \mathrm{~h}$ & $\mathrm{BG} 2.5 \mathrm{~h}$ & $\begin{array}{l}\text { Hetero- } \\
\text { geneity }\end{array}$ & $\begin{array}{l}\mathrm{BG} \\
{[1 \mathrm{~h}+2.5 \mathrm{~h}]}\end{array}$ \\
\hline MCP1 & Novo & 4 & & 177 & 172 & A & $174 \pm 13$ \\
\hline MCP2 & Novo & 4 & & 175 & 163 & $\mathrm{~A}+\mathrm{T}$ & $170 \pm 14$ \\
\hline MCP3 & Novo & 6 & & 179 & 159 & $\mathrm{~T}$ & $167 \pm 13$ \\
\hline MCP6 & FDA & 5 & & 194 & 183 & & $185 \pm 12$ \\
\hline MCP6 & Novo & 6 & 194 & 183 & 179 & $A * T$ & $178 \pm 12$ \\
\hline MCP7 & FDA & 5 & & 197 & 164 & $A+T$ & $175 \pm 13$ \\
\hline MCP7 & Novo & 4 & 204 & 185 & 162 & $A+T$ & $170 \pm 15$ \\
\hline MCP8 & FDA & 5 & & 198 & 177 & $\mathrm{~T}$ & $187 \pm 14$ \\
\hline MCP8 & Novo & 6 & 196 & 186 & 161 & $\mathrm{~A}+\mathrm{T}$ & $166 \pm 10$ \\
\hline $\mathrm{MCB} 2$ & Novo & 4 & & 187 & 195 & & $194 \pm 16$ \\
\hline MCB3 & Novo & 4 & & 189 & 189 & & $189 \pm 13$ \\
\hline MCB4 & Novo & 4 & & 160 & 185 & $\mathrm{~A}$ & $178 \pm 16$ \\
\hline MCB5 & FDA & 6 & & 185 & 195 & & $191 \pm 16$ \\
\hline MCB5 & Novo & 11 & 159 & 162 & 183 & $\mathrm{~T}$ & $177 \pm 10$ \\
\hline MCB6 & FDA & 5 & & 175 & 186 & & $183 \pm 14$ \\
\hline MCB6 & Novo & 4 & 177 & 182 & 182 & & $181 \pm 14$ \\
\hline MCH1 & Novo & 4 & 247 & 191 & 178 & $A+T$ & $184 \pm 12$ \\
\hline $\mathrm{MCH} 2$ & Novo & 4 & 208 & 187 & 164 & $\mathrm{~T}$ & $175 \pm 15$ \\
\hline $\mathrm{MCH} 3$ & Novo & 8 & & 182 & 166 & $\mathrm{~T}$ & $173 \pm 9$ \\
\hline $\mathrm{MCH} 4$ & Novo & 6 & 205 & 170 & 157 & $\mathrm{~T}$ & $166 \pm 10$ \\
\hline MCH5 & Novo & 3 & 196 & 177 & 178 & & $179 \pm 14$ \\
\hline
\end{tabular}

Statistically significant heterogeneity in potency $(p<0.05)$ is indicated as follows: A+T: assays and sampling times (additive effects on log-potency), $\mathrm{A}^{*} \mathrm{~T}$ : assays and sampling times (non-additive effects on log-potency), A: assays only, $\mathrm{T}$ : sampling times only

\section{Results}

\section{Porcine, bovine and human insulin, International Standard}

The results of 468 single rabbit assays on porcine ( $\mathrm{RC}$ and $\mathrm{MC}$ ), bovine (RC and $\mathrm{MC}$ ) and human (MC and BS) insulin relative to the International Standard are shown in Tables 2 and 3. Of these, 298 assays were carried out in the Novo laboratory and 170 in the FDA laboratory. The potency estimates are determined from the blood glucose responses $1 \mathrm{~h}$ and $2.5 \mathrm{~h}$ after the injection, plus, in some cases, also after $30 \mathrm{~min}$, and are expressed in either IU/mg nitrogen or percent of labelled potency. The columns to the right show the univariate potencies with $95 \%$ confidence limits calculated by standard methods for twin cross-over assays using as response the sum of the $1 \mathrm{~h}$ and $2.5 \mathrm{~h}$ blood glucose values [20, 24]. The remaining potencies corresponding to the 30-min, 1-h, and 2.5-h responses are obtained by the multivariate analysis with tests for heterogeneity $[6,7]$.

By the multivariate and univariate statistical analyses no significant deviations from parallelism of the log- dose response curves could be detected in these assays. The tests of homogeneity that were carried out in connection with the combination of results of single assays on the same batch showed, however, significant $(p<$ 0.05 ) heterogeneity to be present in 32 out of the 63 batches assayed at Novo and in 10 out of the 32 batches assayed at FDA.

Combined (weighted mean) potencies of porcine, bovine and human insulins from Tables 2 and 3, together with the underlying potencies of each batch, are shown in Figures 1 and 2. The combined potencies of $\mathrm{MC}$ porcine and $\mathrm{MC}$ and $\mathrm{BS}$ human insulins decrease by $4 \%$ and $9 \%$, respectively, from the $30 \mathrm{~min}$ to the $1 \mathrm{~h}$ response and further by $8 \%$ and $9 \%$ from the $1 \mathrm{~h}$ to the $2.5 \mathrm{~h}$ response. The combined potency of $\mathrm{MC}$ bovine insulin increases by $3 \%$ from the $30 \mathrm{~min}$ to the $1 \mathrm{~h}$ response and further by $6 \%$ from the $1 \mathrm{~h}$ to the $2.5 \mathrm{~h}$ response. Similar but somewhat smaller potency differences are present in assays of $\mathrm{RC}$ porcine and bovine insulins. The decrease and increase in combined potencies (weighted means from both laboratories) for these insulins from the $1 \mathrm{~h}$ to the $2.5 \mathrm{~h}$ response are $6 \%$ and $4 \%$, respectively. The smaller potency differences in as- 
Table 4. MC porcine, MC bovine and MC human insulin batches relative to MC porcine insulin batches

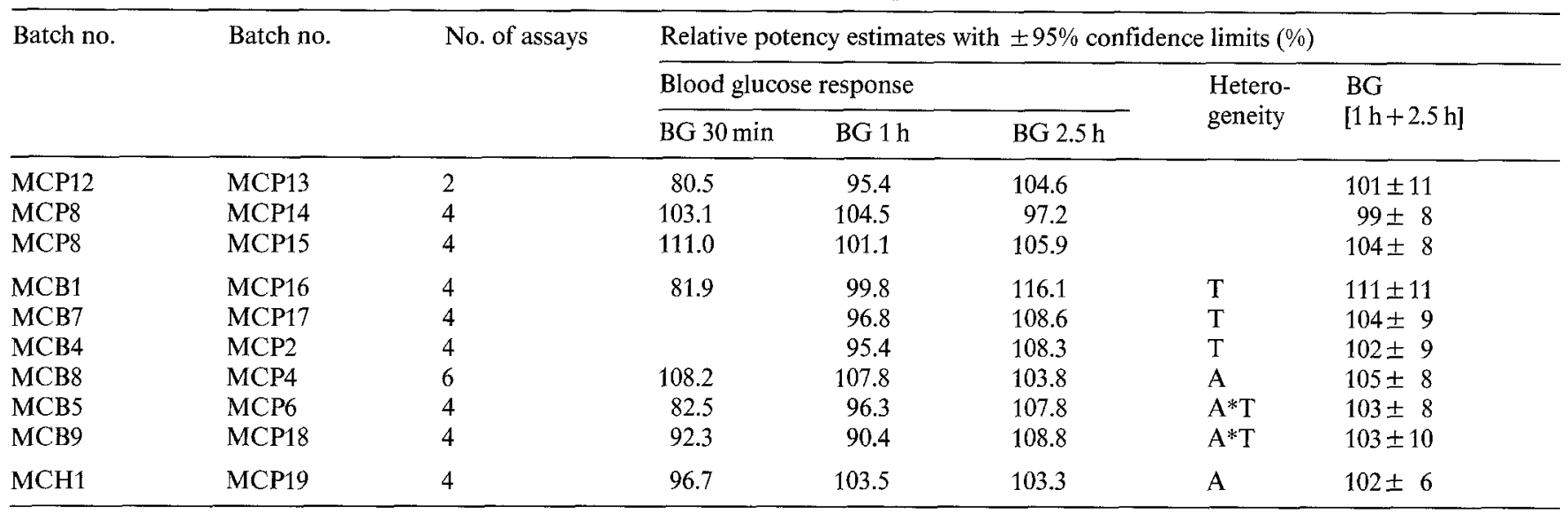

Statistically significant heterogeneity in potency $(p<0.05)$ is indicated as follows: A*T: assays and sampling times (non-additive effects on logpotency), A: assays only, T: sampling times only

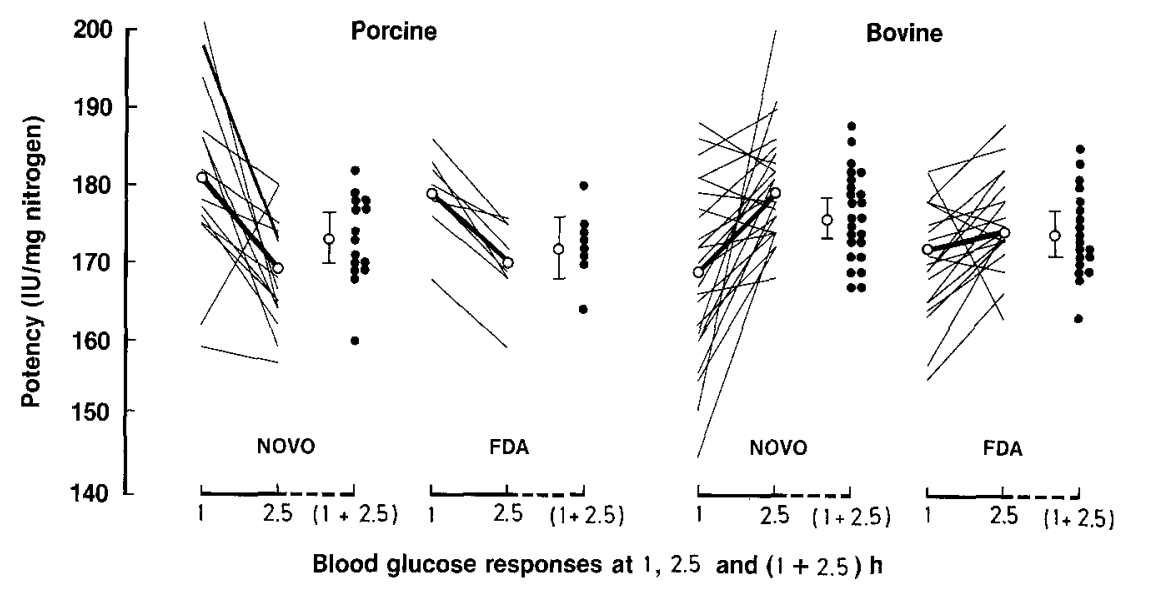

Fig. 1. Combined (weighted mean) multivariate potency based on blood glucose responses at $1 \mathrm{~h}$ and $2.5 \mathrm{~h}$ and combined (weighted mean) univariate (USP method) potency based on the sum of the 1-h and 2.5-h responses for 15 batches of $\mathrm{RC}$ porcine and 24 batches of $\mathrm{RC}$ bovine insulin relative to the International Standard $\left(\mathrm{O}_{-} \mathrm{O}\right)$. The vertical bars indicate $95 \%$ confidence limits. The underlying potencies of each batch are connected with thin lines (multivariate potencies) and shown as points (univariate potencies) says of RC insulins can be explained by the presence of impurities with a timing of action different from that of insulin. The RC insulins as well as the standard contain, for instance, $2-3 \%$ proinsulin, proinsulin-intermediates and other proinsulin-like substances (Table 1) which have a prolonged hypoglycaemic effect compared to insulin.

Mean blood glucose curves from six assays of one batch of human insulin relative to the International Standard (MCH4 in Table 3) are shown in Figure 3.

\section{$M C$ porcine, bovine and human insulin $/ M C$ porcine insulin}

The results of 40 single rabbit assays all carried out in the Novo laboratory on MC porcine, bovine and human insulin relative to $\mathrm{MC}$ porcine insulin are shown in Table 4. The potencies are determined from the blood glucose responses $1 \mathrm{~h}$ and $2.5 \mathrm{~h}$ after the injection plus, in some cases, also after $30 \mathrm{~min}$, and are expressed in percent of the molar potency $\left(168 \cdot 10^{6} \mathrm{IU} / \mathrm{mol}\right.$ insulin $\sim 184 \mathrm{IU} / \mathrm{mg}$ nitrogen) [25]. The columns to the right show the univariate potencies with $95 \%$ confidence lim- its calculated by standard methods for twin cross-over assays using as response the sum of the $1 \mathrm{~h}$ and $2.5 \mathrm{~h}$ blood glucose values [20, 24]. The remaining potencies, corresponding to the $30 \mathrm{~min}, 1 \mathrm{~h}$, and $2.5 \mathrm{~h}$ responses, are obtained by the multivariate analysis with tests for heterogeneity $[6,7]$.

By the multivariate and univariate statistical analy ses, no significant deviations from parallelism of the logdose response curves could be detected in these assays. The tests of homogeneity that were carried out in connection with the combination of results of single assays on the same batch showed, however, significant $(p<$ 0.05 ) heterogeneity to be present in all assay combinations where the test and standard were of different species, whereas no assay combinations where porcine insulin was assayed relative to porcine insulin showed significant heterogeneity.

Combined (weighted mean) potencies of the MCB/ MCP assays from Table 4 together with the underlying potencies of each batch are shown in Figure 4. The combined potency of $\mathrm{MC}$ bovine relative to $\mathrm{MC}$ porcine insulin increase by 3\% from the $30 \mathrm{~min}$ to the $1 \mathrm{~h}$ response and further by $11 \%$ from the $1 \mathrm{~h}$ to the $2.5 \mathrm{~h}$ re- 


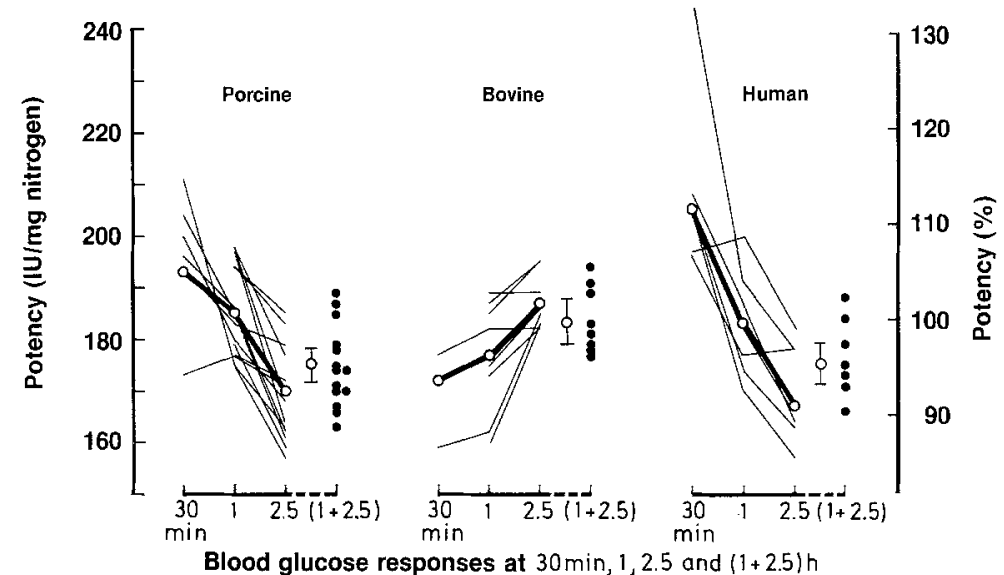

Fig. 2. Combined (weighted mean) multivariate potency based on blood glucose responses at $30 \mathrm{~min}, 1 \mathrm{~h}$ and $2.5 \mathrm{~h}$ and combined (weighted mean) univariate (USP method) potency based on the sum of the 1-h and 2.5-h responses for 11 batches of MC porcine, 6 batches of MC bovine, 5 batches of MC human and 2 batches of BS human insulin relative to the International Standard $\mathrm{O}-\mathrm{O}$. The vertical bars indicate $95 \%$ confidence limits. The underlying potencies of each batch are connected with thin lines (multivariate potencies) and shown as points (univariate potencies)

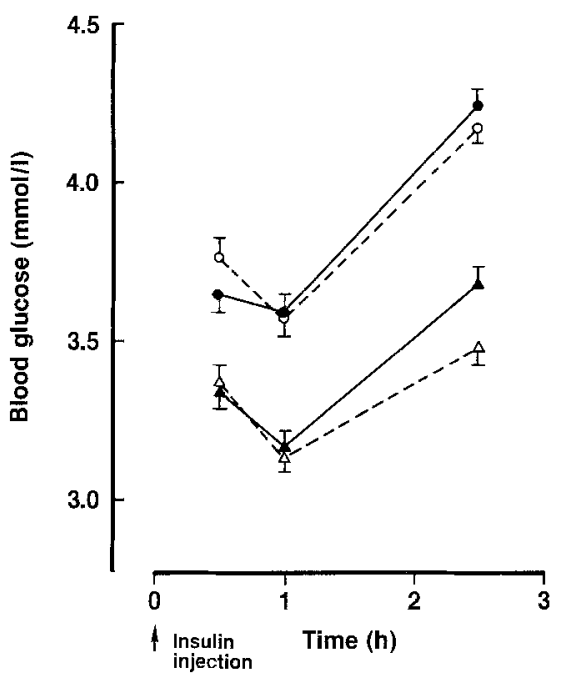

Fig. 3. Blood glucose curves from six repeated assays (168 rabbits) of a batch of MC human insulin relative to the International Standard. The dose injected was either $0.5 \mathrm{IU} / \mathrm{rabbit}$ (human - Standard O-..-O) or $1.0 \mathrm{IU} / \mathrm{rabbit}$ (human $\Delta-\mathbf{\Lambda}$, Standard $\Delta \cdots \Delta$ ). Each point and interval represents the mean \pm SEM

sponse. Mean blood glucose curves from four assays of one batch of bovine relative to one batch of porcine insulin (MCB1/MCP16 in Table 4) are shown in Figure 5.

\section{Discussion}

The results indicate a systematic response time-dependent variation in potency in the rabbit bioassay when the test and standard are of different species composition. For instance, 36 out of 37 assays of porcine insulin and 6 out of 7 assays of human insulin relative to the mixed species standard show a higher potency estimate with the 1 -h response than with the 2.5 -h response, whereas 40 out of 51 assays of bovine insulin show a lower potency estimate with the 1-h response than with the 2.5-h response (Tables 2 and 3). The 30-min response gives an even higher/lower potency estimate. Since the standard is a $52: 48$ mixture of bovine and porcine insulin, these results could be due to porcine and human insulin having a quicker onset and shorter duration of hypoglycaemic effect in rabbits than bovine insulin. That porcine insulin in fact has a quicker and less prolonged hypoglycaemic effect is shown directly in Figure 5, where mean blood glucose curves of bovine relative to porcine insulin are compared. Figure 3 illustrates in a similar way that human insulin has a quicker and less prolonged hypoglycaemic effect compared with the mixed bovine/porcine insulin standard. The data in Table 3 and Figure 2 indicate that human insulin may have an even quicker onset than porcine insulin.

The systematic response time-dependent variation in potency is the same, no matter which laboratory/rabbits have been used in the bioassays. The potency of porcine, bovine and human insulin relative to the present International mixed species Standard cannot be expressed by a single number, since potency varies with the blood sampling time. This invalidity is due to differences between the standard and the unknown, as the assay per definition must be valid when these are identical. In the pharmacopoeial bioassay design (response: blood glucose $[1+2.5]$ h) using the International Standard as the standard the response time-dependent variation in potency results in an, on the average, $5 \%$ underestimation of the potency of MC porcine and MC and BS human insulin $(175 \mathrm{IU} / \mathrm{mg}$ nitrogen instead of $184 \mathrm{IU} / \mathrm{mg}$ nitrogen), whereas MC bovine insulin accidentally gives an estimate very close to the molar potency of these pure insulins $\left(168 \cdot 10^{6} \mathrm{IU} / \mathrm{mol}\right.$ insulin $184 \mathrm{IU} / \mathrm{mg}$ nitrogen) [25]. One could suggest that, by selection of a suitable blood sampling time or by designing a special combination of the responses measured at different times, it might be possible to make the rabbit blood glucose assay insensitive to the differences between the three insulin species. Considering the biological variation in the blood glucose curves, such an approach cannot be expected to solve the problem in general. The use of an insulin standard of the same species or species mixture as the unknown will, however, secure that the assay gives valid results. 


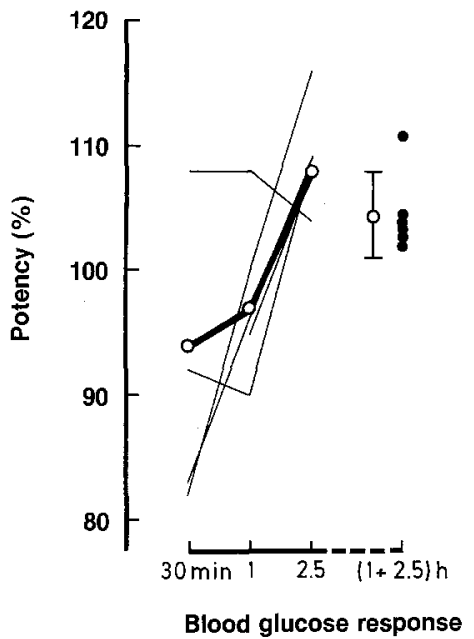

Fig.4. Combined (weighted mean) multivariate potency based on blood glucose responses at $30 \mathrm{~min}, 1 \mathrm{~h}$ and $2.5 \mathrm{~h}$ and combined (weighted mean) univariate (USP method) potency based on the sum of the 1-h- and 2.5-h responses for six batches of MC bovine insulin, using six batches of MC porcine insulin as standard ( 26 assays in all) $\mathrm{O}-\mathrm{O}$. The vertical bars indicate $95 \%$ confidence limits. The underlying potencies of each batch are connected with thin lines (multivariate potencies) and shown as points (univariate potencies)

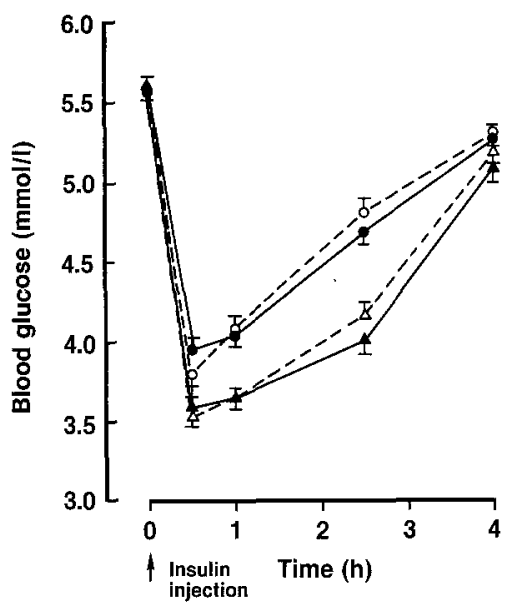

Fig. 5. Blood glucose curves from four repeated assays (112 rabbits) of a batch of MC bovine insulin relative to a batch of MC porcine insulin. The dose injected was either $0.5 \mathrm{IU} / \mathrm{rabbit}$ (bovine - , porcine $0-\mathrm{O}$ ) or $1.0 \mathrm{IU} /$ rabbit (bovine $\Delta-\Delta$, porcine $\Delta-\Delta$ ). Each point and interval represents the mean \pm SEM

In this connection it should be mentioned that there is no evidence of any problem with the other officially accepted pharmacopoeial bioassay systems - the mouse convulsion and the mouse blood glucose assay - concerning differences in the timing of the hypoglycaemic effect of various insulin species, and that no statistically significant differences between mean biological potencies of MC porcine, bovine and human insulins have been found in the mouse convulsion assay [25].

In addition to the systematic response time-dependent variation in potency, the results in the right column of Table 3 illustrate the random variation in potency es- timates of the pure and uniform MC insulins ( $>99 \%$ insulin), which is solely due to variations in the assay. To avoid the inevitable batch-to-batch variation in the final insulin preparations, if the potency is assessed based on a bioassay, the potency of the pure insulins should be defined on a molar basis and assessed based on accurate chemical analysis [25, 26]. Bioassays should be performed in addition to various modern analytical methods, including the RIA and HPLC, to ensure identity and purity of the insulins. This is in accordance with the recommendation given by Home and Alberti [27] in their review of human insulin, "what is required for studies in humans is a comparison of equimolar amounts of human and pork insulin, not equivalent activities in mouse or rabbit".

Clinical studies of human and porcine insulin have shown a tendency to a more rapid onset of hypoglycaemic effect with the human insulin - both semisynthetic and biosynthetic - when neutral soluble preparations are injected subcutaneously into normal subjects [28-30]. In some studies a stronger overall hypoglycaemic effect of the human insulin has been observed [31-34]. Pharmacokinetic studies have indicated that neutral soluble human insulin tends to be more quickly absorbed after subcutaneous injection than the corresponding porcine insulin [28, 33-37]. In a recent study where neutral solutions of human, porcine and bovine insulin were injected subcutaneously into normal subjects, significant differences in hypoglycaemic effect similar to those seen in the rabbit bioassay - have been found [38].

In conclusion, porcine and human insulin have a quicker onset and shorter duration of hypoglycaemic effect in rabbits than bovine insulin. Human insulin may have an even quicker onset than porcine insulin similar to the tendency seen in some clinical studies. In the rabbit bioassay this results in a response time-dependent variation in potency when the test and standard insulin have a different species composition. Hence, pure species insulin standards - a porcine, a bovine and a human standard - are needed for assays of porcine, bovine and human insulin in this bioassay system.

Acknowledgements. The authors wish to thank K. Hag, B. Jensen and G. Zachariassen for their assistance with the statistical analysis and preparation of the manuscript. The editor and referees are thanked for a number of suggestions that have improved the text.

\section{References}

1. Chawdhury SA, Dodson EJ, Dodson GG, Reynolds CD, Tolley S, Cleasby A, Wood SP, Pitts JE (1982) The crystal structure of twozinc human insulin. In: Gueriguian JL, Bransome ED, Outschoorn AS (eds) Hormone drugs, proceedings of the FDA/USP Workshop on Drug and Reference Standards for Insulins, Somatropins and Thyroid-axis Hormones. United States Pharmacopeial Convention Inc, Rockville, pp 106-115

2. Schlichtkrull J (1956) Insulin crystals II. Shape of rhombohedral 
zinc-insulin crystals in relation to species and crystallization media. Acta Chem Scand 10: 1459-1464

3. Schlichtkrull J (1958) Insulin crystals. Chemical and biological studies on insulin crystals and insulin zinc suspensions. Dissertation, Copenhagen University

4. Schlichtkrull J, Pingel M, Heding LG, Brange J, Jørgensen KH (1975) Insulin preparations with prolonged effect. In: Hasselblatt A, Bruchhausen Fv (eds) Insulin II, Handbook of Experimental Pharmacology XXXII/2. Springer, Berlin Heidelberg New York, pp 729-777

5. Vølund Aa, Pingel M, Sørensen E (1982) Differential potency of pork and beef insulin in the USP rabbit bioassay system. In: Gueriguian JL, Bransome ED, Outschoorn AS (eds) Hormone drugs, Proceedings of the FDA/USP Workshop on Drug and Reference Standards for Insulins, Somatropins and Thyroid axis Hormones. United States Pharmacopeial Convention Inc, Rockville, pp 208-215

6. Vølund Aa (1980) Multivariate bioassay. Biometrics 36: 225-236

7. Vølund Aa (1982) Combination of multivariate bioassay results. Biometric 38: 181-190

8. Markussen J (1981) Human Monocomponent Insulin aus Schweine-Rohinsulin. In: Petersen KG, Schlüter KT, Kerp L (eds) Proceedings First International Symposium: Neue Insuline. Freiburger Graphische Betriebe 1982, pp 38-44

9. Chance RE, Kroeff EP, Hoffmann JA, Frank BH (1981) Chemical, physical and biologic properties of biosynthetic human insulin. Diabetes Care 4: 147-154

10. Jørgensen KH, Brange J, Hallund O, Pingel M (1970) A method for the preparation of essentially pure insulin. In: Rodrigues RR, Ebling FJG, Henderson I, Assan R (eds) International congress series No. 209. VII Congress of the International Diabetes Federation, Amsterdam, Excerpta Medica Foundation. Abstract p 149

11. Schlichtkrull J, Brange $\mathbf{J}$, Christiansen $\mathrm{AH}$, Hallund $\mathrm{O}$, Heding LG, Jørgensen KH (1972) Clinical aspects of insulin - antigenicity. Diabetes 21 (Suppl 2): 649-656

12. Schlichtkrull J, Brange J, Christiansen $\mathrm{AH}$, Hallund $\mathrm{O}$, Heding LG, Jørgensen KH, Rasmussen SM, Sørensen E, Vølund Aa (1974) Monocomponent insulin and its clinical implications. Horm Metab Res (Suppl 5): 134-143

13. Heding LG, Larsen UD, Markussen J, Jørgensen KH, Hallund O (1974) Radioimmunoassays for human, pork and ox C-peptides and related substances. Horm Metab Res (Suppl) 5: 40-43

14. Heding LG (1971) Radioimmunological determination of pancreatic and gut glucagon in plasma. Diabetologia 7: 10-19

15. Tronier B (1979) Radioimmunological determination of pancreatic polypeptide. 14th Ann Meeting of the Scandinavian Society for the Study of Diabetes, Oulu. Acta Endocrinol 91 [Suppl] 227: 72

16. Tronier B, Larsen UD (1982) Somatostatin-like immunoreactivity in man. Measurement in peripheral plasma. Diabete Metab 8: $35-40$

17. Fahrenkrug J, Muckadell OBS de (1977) Radioimmunoassay of vasoactive intestinal polypeptide (VIP) in plasma. J Lab Clin Med 89: $1379-1388$

18. Markussen J, Damgaard U, Pingel M, Snel L, Sørensen AR, Sørensen E (1983) Human insulin (Novo): chemistry and characteristics. Diabetes Care 6: 4-8

19. Jørgensen KH, Hallund O, Heding LG, Tronier B, Falholt K, Damgaard U, Thim L, Brange J (1982) Estimation of insulin purity in light of developments in analytical methods. In: Gueriguian JL, Bransome ED, Outschoorn AS (eds) Hormone Drugs, Proceedings of the FDA/USP Workshop on Drug and Reference Standards for Insulins, Somatropins and Thyroid-axis Hormones. United States Pharmacopeial Convention Inc, Rockville. pp 139-147

20. United States Pharmacopeia (1980) Design and analysis of biological assays. Insulin assay, pp 891-901

21. Bangham DR, Mussett MV (1959) The fourth international standard for insulin. Bull WHO 20: 1209-1220

22. Hoffman WS (1937) A rapid photoelectric method for the determination of glucose in blood and urine. $\mathrm{J}$ Biol Chem 120: 51-55
23. Léon P, Sansur M, Snyder LR, Horváth C (1977) Continuous flow analysis for glucose, triglycerides, and ATP with immobilized enzymes in tubular form. Clin Chem 23: 1556-1562

24. Finney DJ (1971) A twin cross-over assay of insulin. In: Statistical method in biological assay. Griffin, London, pp 267-272

25. Pingel M, Vølund Aa, Sørensen E, Sørensen AR (1982) Assessment of insulin potency by chemical and biological methods. In: Gueriguian JL, Bransome ED, Outschoorn AS (eds) Hormone drugs, Proceedings of the FDA/USP Workshop on Drug and Reference Standards for Insulins, Somatropins and Thyroid-axis Hormones. United States Pharmacopeial Convention Inc, Rockville, pp 200-207

26. Kroeff EP, Chance RE (1982) Applications of high-performance liquid chromatography for analysis of insulins. In: Gueriguian JL, Bransome ED, Outschoorn AS (eds) Hormone drugs, Proceedings of the FDA/USP Workshop on Drug and Reference Standards for Insulins, Somatropins and Thyroid-axis Hormones. United States Pharmacopeial Convention Inc, Rockville, pp 148-162

27. Home PD, Alberti KGMM (1982) Human insulin. Clin Endocrinol Metab 11: 453-483

28. Federlin K, Laube H, Velcovsky HG (1981) Biologic and immunologic in vivo and in vitro studies with biosynthetic human insulin. Diabetes Care 4: 170-174

29. Keen H, Pickup JC, Bilous RW, Glynne A, Viberti GC, Jarrett RJ (1980) Human insulin produced by recombinant DNA technology: safety and hypoglycaemic potency in healthy men. Lancet 2 : 398-401

30. Owens DR, Jones MK, Hayes TM, Heding LG, Alberti KGMM, Home PD, Burrin JM, Newcombe RG (1981) Human insulin: study of safety and efficancy in man. Br Med J 282: 1264-1266

31. Chisholm DJ, Kraegen EW, Hewett MJ, Lazarus L (1983) Comparison of potency of porcine insulin and semisynthetic human insulin at 3 dose levels using the euglycaemic clamp. Horm Metab Res 15:415-418

32. Schlüter KJ, Enzmann F, Kerp L (1983) Different potencies of biosynthetic human and purified porcine insulin. Horm Metab Res 15: 271-274

33. Sonnenberg GE, Kenner FW, Cüppers HJ, Berger M (1983) Subcutaneous use of regular human insulin (Novo): pharmacokinetics and continuous insulin infusion therapy. Diabetes Care 6: 35-39

34. Sundermann S, Hauff C, Cüppers HJ, Broermann C, Schütte M, Berger M (1981) Absorptionskinetik und biologische Aktivität von semisynthetischem Human-Insulin (Novo). Aktuel Endocrinol Stoffw 2: 116

35. Bottermann P, Gyarame H, Wahl K, Ermlu R, Lebender A (1981) Pharmacokinetics of biosynthetic human insulin and characteristics of its effect. Diabetes Care 4: 168-169

36. Pramming S, Lauritzen T, Thorsteinsson B, Johansen $K$, Binder C (1984) Absorption of soluble and isophane semi-synthetic human and porcine insulim in insulindependent diabetic subjects. Acta Endocrinol 105: 215-220

37. Sestoft L, Vølund Aa, Gammeltoft S, Birch K, Hildebrandt P (1982) The biological properties of human insulin: subcutaneous absorption, receptor binding and the clinical effect in diabetics assessed by a new statistical method. Acta Med Scand 212:21-28

38. Owens DR, Jones MK, Birtwell AJ, Burge CTR, 'Jones IR, Heyburn PJ, Hayes TM, Heding LG (1984) Pharmacokinetics of subcutaneously administered human, porcine and bovine neutral soluble insulin in normal man. Horm Metabol Res 16: 195-199

Received: 28 August 1984

and in revised form: 26 August 1985

Dr. Marianne Pingel

Novo Research Institute

Novo Allé

DK-2880 Bagsvaerd

Denmark 